\title{
Greek Registered Nurses' Job Satisfaction in Relation to Work-Related Stress. A Study on Army and Civilian Rns.
}

\author{
Malliarou Maria (Corresponding author) \\ Scientific collaborator Technological Institution of Larisa \\ Nursing Department, Terpsithea Larisa 41500, Greece \\ Tel: 30-241-085-1742Ｅ-mail:mmalliarou@gmail.com \\ Sarafis Pavlos \\ Faculty of Human Movement and Quality of Life Sciences \\ University of Peloponnese, Department of Nursing, Sparta, Greece \\ E-mail: psarafis@uop.gr,psarafis@gmail.com \\ Moustaka Eleni \\ Athens, Greece \\ E-mail: emoustaka73@yahoo.gr
}

\author{
Kouvela Thamme \\ Athens, Greece
}

Tel: 30-210-639-4334

Constantinidis T.C

Laboratory of Hygiene and Environmental Protection

Postgraduate Programme Health and Safety in Workplace

Medical School, Democritus University of Thrace, Greece

E-mail: tconstan@med.duth.gr

\begin{abstract}
Background: Job satisfaction and work-related stress effect, job turnover, and patient satisfaction in nursing.

Aim: To present the views of Greek Army Registered Nurses and Civilian Registered Nurses on job satisfaction and job stress and why they are lead to seeking employment elsewhere.

Methods: A descriptive, cross-sectional study was undertaken by questionnaire on a random sample of 117 Registered Nurses (77 Army RNs - 40 Civilian RNs), (Response rate 42\%). The Warr-Cook-Wall job satisfaction scale was used to measure overall job satisfaction. Job related tension index was used to measure nurses' levels of stress. The association between relationship factors and organizational outcomes such as job satisfaction, turnover intentions and organizational commitment were assessed. The analysis was made with the use of SPSS (version 15).

Results: Mean score of stress was for Army Registered Nurses (RNs) m=31.61 (SD 9.041 $\min =21 \mathrm{max}=75$ ) while for Civilian Registered Nurses was $\mathrm{m}=29.38$ (SD $7.117 \mathrm{~min}=12$ max=46) The most frequently mentioned source of job stress for civilian RNs is not having a say on the appearance and structure of their work environment $(p=0.017)$. Not being appreciated and not treated as equal to other health professionals. $(p<0.0001)$. Civilian RNs' occupational stress leads to their leaving the workplace $(p=0.004)$. Results of the regression analysis when performing Pearson correlation coefficients (correlation significance at the level 0.05 two-tailed)
\end{abstract}


showed that the increase in job satisfaction of Army RNs was predicted by older nurses $\mathrm{p}=0.001, \mathrm{r}=0.363$, by more experienced ones with more years at work $\mathrm{p}=0.004, \mathrm{r}=0.326$.

Conclusions: A nursing career is fulfilling when the nurse is given the opportunity to provide input on decisions in the workplace, is treated as an equal to other health professionals and is given recognition for accomplishments. The current shortage of nurses highlights the importance of understanding the impact of low moral and stress in the workplace and the need to implement innovative programs that respect the nursing profession.

Keywords: Job satisfaction, Stress, Job related tension index, Army, Civilian, Nurse

\section{Introduction}

We have taken an in depth look at job satisfaction and work related job stress in civilian Registered Nurses and active duty Army Registered Nurses in Greece. Job satisfaction and stress of Civilian registered nurses in Greece has been examined several times, but Army nurses represent a relatively unexamined population. Moreover, there are distinct differences between Army nurses and civilian nurses. For example, civilian nurses are often older (Association of Military Surgeons of the United States 2009). Army nurses have a larger proportion of males and higher education levels since all RNs are Military Nursing Academy graduates (equal to a university degree). For Military nurses promotion offers instant benefits including public recognition (i.e., through uniform insignia) increased positional authority (i.e., through achieving a higher military rank). These characteristics promote higher self-worth, thus leading to increased job satisfaction (Association of Military Surgeons of the United States).

Researchers contend that job satisfaction is possibly the most significant yet elusive factor in understanding worker motivation, performance and effectiveness, and recruitment and retention (Cavanagh \& Coffin 1992; Snarr \& Krochalk 1996). Job satisfaction is an important component of nurses' lives that can impact on patient safety, productivity and performance, quality of care, retention and turnover, commitment to the organisation and the profession. In this article, the aim is to identify differences in how Army and civilian registered nurses' perceive job satisfaction and work related stress and identify the different working conditions that affect their attitude towards nursing. Job satisfaction is an important determinant of nurses' retention and turnover, and may also affect performance.

Studies have proposed a number of determinants of job satisfaction, including demographic characteristics (age, gender, educational level, race, marital status), job characteristics (absolute and relative wages, number of hours worked, tenure, attitude towards work), and employer characteristics (number of staff) (Clark 1997). Job satisfaction depends on a number of factors and is subject to change. Satisfied nurses' work is more attentive and probably patients are more satisfied.

Following are some definitions of concepts that are important to this study. Status is the hierarchical position one holds in the professional or social community. In the work place, professional status is the ranking of a health care provider in the eyes of his or her peers through compensation of reward and pay. Reward is that which is of value when returned for something positive that was done. Pay is financial compensation for professional duties including fringe benefits, bonuses, and future pay increases. Social status is the chance to be recognized in the community. These factors would be expected to influence organizational work satisfaction positively and have a negative relation to anticipated turnover. Autonomy, collaboration, and research utilization should be factors influencing work satisfaction (Hinshaw \& Atwood 1983; Weiss \& Davis 1985). Control over practice is the factor that references the concept of centralization and the degree of decision-making allotted to individual staff members (Hinshaw et al., 1987). Collaboration is the working together of registered nurses and physicians in sharing responsibility for problem-solving and decision-making in patient care (Weiss \& Davis, 1985). Autonomy is a characteristic of a position that allows or encourages individuals to make major decisions in daily operational activities, equipment used, and procedures. Organizational work satisfaction is the positive opinion of the job in terms of pay or reward, administrative style, professional status and interaction with colleagues (Stamps et al., 1978). Professional job satisfaction is the specific aspect of work that health providers find positive in regard to enjoyment of position, quality of care delivered, and time to conduct ones work (Hinshaw et al., 1987). Identification of factors that influence job satisfaction will help to decrease attrition, and maintain quality care.

Vroom (1964) found that job satisfaction was directly related to the perceived reward outcomes of pay, promotion, interaction with coworkers, an opportunity to influence decisions, and control over their work. He developed a subtractive theory on the motivation to work. He believed job satisfaction was inversely related to the discrepancy between what an individual needs from the job, and what is supplied by the job in terms of needs. 
The traditional model of job satisfaction focuses on all the feelings that an individual has about his/her job. However, what makes a job satisfying or dissatisfying does not depend only on the nature of the job, but also on the expectations that individuals have of what their job should provide.

Based on Maslow's theory, job satisfaction has been approached by some researchers from the perspective of need fulfillment (Kuhlen, 1963; Worf, 1970; Conrad et al., 1985). Herzberg and Mausner (1959) formulated the two-factor theory of job satisfaction and postulated that satisfaction and dissatisfaction were two separate and sometimes even unrelated phenomena. Intrinsic factors which they named 'motivators' (i.e. factors vital to the nature and experience of work) were found to be job 'satisfiers' and included: achievement, recognition, work itself and responsibility. Extrinsic factors which they named 'hygiene' factors were found to be job 'dissatisfiers' and included: company policy, administration, supervision, salary, interpersonal relations and working conditions.

Price and Mueller's theory acknowledged that employees enter the workplace with certain expectations and values. If these expectations and values are found in the workplace, the employee will be more satisfied, committed to the organization, and less likely to leave. The nursing literature is replete with studies linking employee factors and work-related factors with job satisfaction.

Hinshaw and Atwood (1983) also reviewed the literature and identified key factors influencing nurse job satisfaction. Those influencing job satisfaction in multiple settings included age, sex, intelligence, education, experience as a nurse, tenure, and position in the hierarchy. Environmental factors included degree of professionalization, organizational climate, supervision, and interpersonal relationships. Characteristics of the job itself included pay, autonomy, and job outcomes. In studies conducted at military and civilian facilities job satisfaction has been positively related to autonomy, coworker and supervisor support, resource adequacy, professional growth, promotional opportunity, and distributive justice. Stress levels have been shown to be directly related to job satisfaction (Moustaka et al, 2009a). Huber (1995) found in the course of his research on stress in hospital nurses that stress in the workplace has a negative effect on nurses' health, job satisfaction and quality of patient care, and a positive, i.e. exacerbating, effect on absenteeism, job turnover and accidents. A meta-analysis conducted by Blegen (1993) of 48 studies covering 15.048 nurses found that their work satisfaction was negatively associated with stress.

Sources and indicators of stress are varied; however, they could be recognized. Mild to moderate stress may not be observed collectively, thus symptoms at this level of stress are varied and depend on individuals' perceptions of stress (Albar Marin \& Garcia-Ramirez 2005; Bartlett 1998; Maslach et al. 2000; Smith et al. 2000). Nursing provides a wide range of potential workplace stressors as it is a profession that requires high levels of skills, teamwork and provision of continuous care (French et al. 2000; Phillips 1996). French et al. (2000) identified the following workplace stressors: conflict with physicians, inadequate preparation, problems with peers, problems with supervisor, discrimination, workload, uncertainty concerning treatment, dealing with death and dying patients, and patients and their families. Other sources of stress include workload, leadership/management issues, professional conflict, mood disturbances, age and experience, and emotional demands of caring (Malliarou et al. 2009; Finlayson et al. 2002; Healy \& McKay 2000; Hillhouse \& Adler 1997; Payne 2001). In the military, sources of stress could include inadequate staffing, long working hours, duty schedules which are in conflict with time for family, deployments, threat of military disciplines, problem with supervisors and a wide variety of other job related issues (Pflanz \& Ogle, 2006).

\section{Methodology}

Using a cross-sectional design, a paper survey was administered anonymously to registered nurses working at four Army hospitals and one University Hospital of the region in Northern Greece in 2007 (sampling frame in table 2). Hospitals were collected using the random sampling technique. Sample size was based on Tabachnick and Fidell's recommendation that 10 respondents per variable are needed for adequate power in linear regression. Data were collected, after Institutional Review Board approval at the University Hospital. Approval to conduct the study in Army Hospitals was obtained from the General Army Staff/Health Directorate. The return of the questionnaire was considered implied consent. Data was gathered via a self-administered questionnaire. The questionnaire was distributed and administered to respondents by the researcher in a room provided by the department. The researcher explained the objectives of the study and read aloud each item. The eligible nurses included army staff registered nurses with the rank of $2^{\text {nd }}$ Lieutenant through Major and civilian registered nurses in grades A and B. These employment levels were selected because they include most of the nurses who provide clinical care for inpatients. Three forms were used for data collection in this research. A general information questionnaire, recorded the demographic (age, education, marital status) and professional features (professional 
status, weekly work hours, participation in professional activities) of the sample of the study. It was formulated by the investigators according to similar questionnaires found in Greek and international literature. The survey was adjusted to account for military concepts by adding items to address specific military issues such as knowledge of internal regulation of Army hospital, which was the reason for being transferred in the exact unit (their choice- meeting service needs). The second one contained a standardized job satisfaction scale and a standardized work related stress scale. So the whole questionnaire enquired into job satisfaction, work - related stress, intentions to quit, and demographic, job, and practice characteristics. Preliminarily the study established internal consistency by using Cronbach alpha values for both instruments. Additionally, the study determined the level of occupational stress, job satisfaction and relationship between occupational stress and job satisfaction facets. The findings of the study revealed that the reliability of both instruments were greater than 0.80 . Nurses were asked how satisfied they feel with their present job. Pearson's product-moment correlations coefficients (r) were conducted to determine whether a relationship existed between the dependent variable job satisfaction scale ( 1 = extremely dissatisfied to $7=$ extremely satisfied) and the independent variables such as gender, position, marital status, years of service. Descriptive statistics were compared to characterize the demographics characteristics of the military and civilian sample of nurses. The data analysis was realised with statistical methods of descriptive and inductive statistics. The one-sample Kolmogorov-Smirnov test was used to check whether continuous variables were normally distributed. Medians of variables for the two groups were compared using the two independent samples Mann-Whitney $U$ test for not normally distributed, continuous variables. Percentages and mean scores with standard error (SE) were calculated for demographic and workplace characteristics. T-test with $95 \%$ confidence interval (CI) for the differences of means was calculated.

\section{Measures}

\subsection{Job satisfaction}

The Warr-Cook-Wall job satisfaction scale was used to measure overall job satisfaction and satisfaction with fifteen aspects of work. The scale provides a short, reliable, valid and easy-to-use measure of job satisfaction.

Each item was rated on a seven-point Likert scale, where a value of one denotes extreme dissatisfaction and a value of seven reflects extreme satisfaction. The association between relationship factors and organizational outcomes such as job satisfaction, turnover intentions and organizational commitment were assessed. The likelihood that a nurse would resign within the next year was measured on a scale, with increasing values reflecting higher probabilities of quitting. The individual characteristics of military nurses included age, gender, marital status, and number of children. Both descriptive statistics (frequency, percentage, mean and standard deviation) and inferential statistics (Pearson correlation testing) were used for purposes of descriptive and co-relational testing respectively. To identify patterns of job satisfaction and stress by demographic, job, and practice characteristics, the two independent samples t-test was used for normally distributed variables, the two independent samples Mann-Whitney $U$ test was used for not normally distributed variables, and the Pearson chi-square test was used for binary variables. Summary measures were based on the values reported by those who completed the questionnaire. A p-value of $\leq 0.05$ was used as the threshold for a statistically significant result. The analysis was made with the use of SPSS (version 15).

\subsection{Job related tension index}

Job related tension index was developed by Kahn, Wolfe, Quinn and Snoek and describes employee perceptions of job stress using 11 items asking about the frequency of stressful occurrences and the extent of role overload. This measure assesses psychological symptoms of stress such as feelings of having too much work, not having the means and materials to accomplish assignments or projects and generally being unable to handle all of the work. Response options are: $1=$ never, $2=$ rarely, $3=$ sometimes, $4=$ rather often, $5=$ nearly all the time. Responses were obtained on a summated rating scale format ranging from "never" to "rather often". Higher scores indicated higher perceived occupational stress.

\section{Results}

In table 1 there are all the demographic information of Army RNs and Civilian RNs. A total of 117 usable questionnaires were returned (response rate 42\%). The sample comprised of 40 civilian RNs and 77 Army Registered Nurses. Most of Civilian RNs were women 95\% while women Army RNs were only 39\%. The mean age of respondents for two groups were almost the same with two years of difference (civilian RNs $36.2 \pm$ 7.5years, army RNs $34.18 \pm 5.95$ years) but there were distinct differences in the percentage of personnel being above 36 years old. As we can see only $39 \%$ of the military nurses were above 36 as compared to $65 \%$ of the civilian nurses. Most Army RNs were married $(n=55)$ having 1-2 children $(n=49)$ and they had a work experience of up to 15.07 years (SD 6.22 years). Two of Army RNs possessed Masters Degree and only $6.4 \%$ 
had a nursing specialization title, 53.2\% of Army RNs didn't have additional nursing education (i.e. master, nursing specialty) after graduating military nursing academy. $13 \%$ were head nurses and $54.5 \%$ worked in inpatients services. Concerning the work environment, 55.8\% of the army RNs was working only one shift (day shift). Mean number of night shifts per person in a month was 2.05. 24 out of 40 of civilian RNs were married and 28 had children. $72.5 \%$ had no additional education after graduation and they had 12.16 years as working experience. $25 \%$ were head nurses and only $22.5 \%$ of the civilians were working in the morning shift. 3.1 were the mean days working night shift per month.

In table 3, there are the answers the two groups gave in certain questions concerning their willingness to resign, to demand changes in working conditions, if they would like their child to follow nursing profession, if they would choose same profession again, their attitude towards health professional team, their beliefs about prestige of nursing profession in society and many others. Both groups would like their child to follow nursing career (army RNs 71.4\% - civilian RNs 85\%). Almost half of the respondents wouldn't choose nursing profession again (army RNs 53.2\% - civilian RNs 62.5\%). A large amount of the respondents would like to change their everyday duties in order to feel independent health professionals (army RNs 83.1\% - civilian RNs 90\%). Also they feel that their opinion doesn't count in health professional's team (army RNs 57.1\% - civilian RNs 67.5\%). Civilian RNs (87.5\%) as well as army RNs (77.9\%) share the idea that the doctor-centred model of Greek Hospitals creates difficulties in the team work. There is a slight difference in answered percentages about the way they see nursing profession, if it is socially awarded with the majority to agree that it isn't (army RNs 63.6\% - civilian RNs $85 \%$ ). Almost all of the respondents agree that there is a huge dimension between their professional expectations and the reality they live in (army RNs 90.9\% - civilian RNs 97.5\%). One third of Army RNs are willing to quit job and one quarter of civilian ones want to do the same.

Overall, levels of job satisfaction were high for two groups. The overall job satisfaction was found to be 100.87 out of 105 for Army RNs and 94.43 for Civilian ones.

In table 4 the differences in job related tension index between the two groups are shown.

A correlation of Army RNs and civilian ones and satisfaction items of the scale revealed the following results. Performing "independent samples" $t$-test it was found that men civilian RNs were significantly more likely to be very satisfied $(\mathrm{p}=0.037)$ as well as Civilian $\mathrm{RNs}$ who had the opportunity to decide the unit they work to $(\mathrm{p}=0.012)$. As it is shown in table 6 civilian RNs with additional education after graduation are more satisfied with "freedom to choose method of working" ( $p=0.039)$, with "opportunities to use abilities" $(p=0.039)$ and with "amount of variety in job" ( $\mathrm{p}=0.019)$. Those civilian RNs who answered that they want to resign and quit profession are less satisfied with their "opportunity to use abilities" $(\mathrm{p}=0.014)$ and with "freedom to choose method of working" ( $p=0.042)$. Those who weren't satisfied by their head nurse they wouldn't choose the same profession again $(\mathrm{p}=0.032)$. Civilian RNs without children were more satisfied by the "Amount of variety in job" $(\mathrm{p}=0.049)$.

"Hours of work" ( $\mathrm{p}=0.039)$ and "colleagues and fellow workers" $(\mathrm{p}=0.007)$ are items that married Army RNs are more satisfied. Married Army RNs are satisfied with "freedom to choose method of working" $p=0.049$. "Opportunity to use ability" is one item of job satisfaction that would make Army RNs to choose their profession again $(\mathrm{p}=0.024)$. Those Army RNs that answered that they would like their child to follow nursing career were more satisfied by "chances of promotion" ( $\mathrm{p}=0.034)$, by "freedom to choose method of working" $(\mathrm{p}=0.001)$ and by "recognition you get for your good work" ( $\mathrm{p}=0.001)$. A correlation was found between Army RNs who wanted the modification of their job description and the "amount of variety in job" ( $\mathrm{p}=0.028)$ and "opportunity to use ability" ( $\mathrm{p}=0.001)$ (table 6).

Results of the regression analysis when performing Pearson correlation coefficients (correlation significance at the level 0.05 two-tailed) showed that the increase in job satisfaction of Army RNs was predicted by older nurses $\mathrm{p}=0.001, \mathrm{r}=0.363$, by more experienced ones with more years at work $\mathrm{p}=0,004, \mathrm{r}=0.326$. Married Army RNs were found to be more satisfied by the "freedom to choose method of working" $p=0.049$. Table 5 shows the percentages of satisfied, unsatisfied and those who were not sure Army RNs and Civilian RNs with each item of job satisfaction scale.

Table 7 shows median job satisfaction scores among army registered nurses (67) and Civilian registered Nurses (69).

In table 5 we can see that the most outstanding difference between the results is the one that shows that civilian RNs $(60 \%)$ are not satisfied by physical working conditions in relation to army RNs $(6,5 \%)$. Remuneration is another aspect that both groups are not satisfied with (army RNs 77.6\% - civilian RNs 57.5\%). Almost half of the respondents are not satisfied by hours of work (army RNs 53.2\% - civilian RNs 50\%). Almost one third of 
the respondents are not satisfied by recognition they get for their good work (army RNs 53 36.4\% - civilian RNs $35 \%$. In table 9 we can see which variables correlate with different items of satisfaction scale. For civilian nurses were age $\mathrm{p}=0.001(r=-0.490)$, years of experience $\mathrm{p}=0.012(r=0.394)$, night shifts per month $\mathrm{p}=0.037(31)$, and work related stress $\mathrm{p}=0.041 \quad(r=0.324)$. The same variables were correlated with different items of satisfaction scale for the Army RNs also as it shown in table 8.

\section{Discussion}

Job satisfaction is a complex phenomenon, as evidenced by the many related factors identified in several studies. The identification of these factors and exploration of their effects on job satisfaction has the potential to refine the theoretical models of nurses' job satisfaction and aid the development of management interventions (Blegen, 1993). Blegen's (1993) meta-analysis found that job satisfaction was most strongly associated with stress and organizational commitment. This study has added additional information to the knowledge concerning job satisfaction in nurses by investigating two distinct nurse populations who work in the Greek health sector. Nurses hold the majority of positions in most health care settings. Nurses who are allowed to practice autonomously, using independent judgment and critical thinking skills, have a greater sense of job satisfaction. Findings of this research suggest that military health organizations, educational preparation, and personal characteristics of registered nurses affect their level of satisfaction. Especially for military nurses there is a challenge to understand their needs and meet their expectations (Malliarou et al, 2009; Moustaka et al, 2009b). The findings from the study suggest a lack of co worker support and lack of social award of the profession were related to dissatisfaction in civilian nurses. That is because Greek Hospitals are doctor-centered something that increases the hindrance of interdisciplinary collaboration. A large percentage of civilian RN's (89.9\%), wants their job description modified so as to be independent health professionals, while only $35,9 \%$ of the sample feels professionally equal with other health professionals.

Strategies that increase teamwork and clarify civilian nursing roles may enhance satisfaction and should be examined. The lack of significant influences of autonomy, and professional growth might be identified as "dissatisfiers" by nurses in this study also. For Army Registered nurses promotion offers instant benefits including public recognition (i.e., through uniform insignia), increased positional authority (i.e., through achieving a higher military rank), and increased pay. These characteristics promote higher self- worth, thus leading to increased job satisfaction. Nurses who perceive opportunities for promotion are more likely to be satisfied. For both groups autonomy, professional status, and pay were the most important factors that influence job satisfaction.

The organisations should take all necessary measures and undertake initiatives for the increase of job satisfaction. More specifically it is proposed (Constantinidis et al, 2006; Malliarou \& Moustaka 2009):

a) The placement of a suitable professional in the right position increases his probabilities of output but also benefit of qualitative care

b) The clarification of professionals' role and duties and their inclusion in the decision-making.

c) The possibility of breaks and special authorisations given by administration

d) The increase of possibilities for professional development.

e) The operation of teams for psychological support

f) Opportunities for further training and education

g) The interdisciplinary collaboration between the members of healthcare team (doctors, nurses, psychologists, psychiatrists, social workers) which presupposes the recognition of role, duties, but also limits of each expert and his contribution in the comprehension of approach and handling of each case.

Several limitations of the study must be acknowledged. Data were collected at 4 Army hospitals; the findings cannot be generalized to all Army hospitals. As with any survey approach to data collection there is the potential for bias in self-report measures. Further investigation into factors affecting military nurses' job satisfaction and civilian nurses' job satisfaction must be explored.

\section{Conclusion}

It is imperative that hospitals strive to monitor and sustain the job and organizational work satisfaction of their nurses. Since the nursing department has the largest number of employees and most of them provide direct care to patients, it is very important that their needs are understood and addressed. Issues concerning job satisfaction, potential for burnout, as well as effect of burnout on patients, expanded knowledge and better understanding of productivity, and, sources of empowerment for RNs in the health care setting should continue to be investigated. 
Improved job satisfaction results in fewer job turnovers, high quality patient care, less physical and mental injuries to health care staff, and improvement of the entire organization. Literature suggests that nurses are experiencing increasing levels of work-related stress over time and increased levels of work-related stress are associated with lower levels of satisfaction with reward packages and working conditions. In conclusion, improvement of remuneration and working conditions of health centres and rationalization of work would be expected to increase job satisfaction and contribute to the overall quality of health services.

\section{References}

Albar Marin, M. J., \& Garcia-Ramirez, M. (2005). Social support and emotional exhaustion among hospital nursing staff. European Journal of Psychiatry, 19 (2), 96-106.

Association of Military Surgeons of the United States. (2009). Registered Nurses' Job Satisfaction in Navy Hospitals. [Online]: Available: http://www.thefreelibrary.com/Registered+Nurses'+Job+Satisfaction+in+Navy+Hospitals-a01611779363 (Dec 12, 2009).

Bartlett, D. (1998). Stress and health. In: Payne, S., Horn, S. (Eds.), Stress, Perspectives and Processes (pp. 1-21). Oxford: Oxford University Press, Health Psychology Series.

Blegen, M. (1993). Nurses' job satisfaction: a meta-analysis of related variables. Nursing Research, 42 (1), 36-41.

Cavanagh, S., \& Coffin, D. (1992). Staff turnover among hospital nurses. Journal of Advanced Nursing, 17 , 1369-1376.

Clark, A. E. (1997). Job satisfaction and gender: Why are women so happy at work? Labour Economics, 4(4), 341-372.

Conrad, K. M., Conrad, K. J. \& Parker, J. E. (1985). Job satisfaction among occupational health nurses, Journal of Community Health Nursing, 2, 161-173.

Constandinidis, T. C., Moustaka, E., \& Malliarou, M. (2006). Professional Stress, burnout syndrome in hygiene and safety of work. Alexandroupolis, Greece: Program of Postgraduate Study Hygiene and Safety of Work, University of Thrace.

Finlayson, B., Dixon, J., Meadows, S., \& Blair, G. (2002). Mind the gap: policy response to the NHS nursing shortage. British Medical Journal, 325, 541-544.

French, S. E., Lenton, R., Walters, V., \& Eyles, J. (2000). An empirical evaluation of an expanded nursing stress scale. Journal of Nursing Measurement, 8 (2), 161-178.

Healy, C., \& McKay, M. F. (2000). Nursing stress: the effect of coping strategies and job satisfaction in a sample of Australian nurses. Journal of Advanced Nursing, 31 (3), 681-688.

Herzberg, F., \& Mausner, B. (1959). The Motivation to Work. (2nd ed.). New York: Wiley.

Kahn, R. L., Wolfe, D. M., Quinn, P. R., Snoek, J. D., \& Rosenthal, R. A. (1964). Organizational Stress: Studies in Role Conflict and Ambiguity. New York: Wiley (in Seo, Y., Ko, J., Price, J. L., 2004. The determinants of job satisfaction among hospital nurses: a model estimation in Korea. International Journal of Nursing Studies, 41, 437-446.)

Hillhouse, J. J., \& Adler, C. M. (1997). Investigating stress effect patterns in hospital staff nurses: result of cluster analysis. Social Science and Medicine, 45 (12), 1781-1788.

Hinshaw, A. S., \& Atwood, J. R. (1983). Nursing staff turnovers, stress, and satisfaction: Models, measures, and management. In Werley H. H., Fitzpatrick J. F. (Eds.). Annual Review of Nursing Research (pp.133-153). New York: Springer.

Hinshaw, A. S., Smeltzer, C. H., \& Atwood, J. R. (1987). Innovative retention strategies for nursing staff. Journal of Nursing Administration, 17 (6), 8-16.

Huber, D. (1995). Understanding the sources of stress for nurses. Australian Journal of Nursing, 12, 87-100.

Kuhlen, R. G. (1963). Needs, perceived need satisfaction opportunities, and satisfaction with occupation, Journal of Applied Psychology, 47 (1), 56-64.

Malliarou, M., \& Moustaka, E. (2009). Nurses' job satisfaction in military hospitals of Northern Greece. 14 ${ }^{\text {th }}$ Congress of BMMC. Multinational Military cooperation on the Balkans and on missions abroad. Sunny Beach, Bulgaria. 
Malliarou, M., Moustaka, E., \& Constantinidis, T. C. (2009). Stress related health problems and management of occupational stress. Public Health and Health Care in Greece and Bulgaria: The Challenge of the Cross-border Collaboration. Alexandroupolis, Greece.

Maslach, C., Shaufeli, B., \& Leiter, M. P. (2000). Job burnout. Annual Review of Psychology, 52, 397-422.

Moustaka, E., Malliarou, M., \& Constantinidis, T. C. (2009a). Occupational stress and the mechanisms through which affects the human health. Public Health and Health Care in Greece and Bulgaria: The Challenge of the Cross-border Collaboration. Alexandroupolis, Greece.

Moustaka, E., Malliarou, M., Sarafis, P., Constantinidis, T. C., \& Manolidou, Z. (2009b). Burnout in Nursing Personnel in a Regional University Hospital. Balkan Military Medical Review, 12(1), 1-7.

Payne, N. (2001). Occupational stressors and coping as determinants of burnout in female hospice nurses. Journal of Advanced Nursing, 33 (3), 396-405.

Pflanz, S. E., \& Ogle, A. D. (2006). Job Stress, Depression, Work Performance and Perceptions of Supervisors in Military Personnel. Military Medicine, 171(9), 861-865.

Phillips, S. (1996). Labouring the emotions: expanding the remit of nursing work? Journal of Advanced Nursing, 24 (1), 139-143.

Smith, A., Brice, C., Collins, A., Mathews, V. \& McNamara, R. (2000). The Scale of Occupational Stress: A Further Analysis of the Input of Demographic Factors and Type of Job. Norwich: HSE Books.

Snarr, C. E., \& Krochalk, P. C. (1996). Job satisfaction and organizational characteristics: results of a nationwide survey of baccalaureate in the nursing faculty. Journal of Advanced Nursing, 24(2), 405-412.

Stamps, P. L., Piedmonte, E. B., Slavitt, D. B., \& Haase, A. M. (1978). Measurement of work satisfaction among health professionals. Medical Care, 16, 337-352.

Tabachnick, B. G., \& Fidell L. S. (2001). Using Multivariate Statistics. (4rth Ed.). Needham Heights, MA: Allyn \& Bacon. pp. 582 - 633.

Vroom, V. H. (1964). Work and Motivation. New York: John Wiley and Sons, Inc.

Warr, P., Cook, J., \& Wall, T. (1979). Scales for the measurement of some work attitudes and aspects of psychological well-being. Journal of Occupational Psychology, 52, 129-148.

Weiss, S. J., \& Davis, H. P. (1985). Validity and reliability of Collaborative Practice Scales. Nursing Research, 34, 299-305.

Worf, M. G. (1970). Need gratification theory: a theoretical reformulation of job satisfaction/dissatisfaction and job motivation. Journal of Applied Psychology, 54, 87-94. 
Table 1. Demographic information of nursing staff

\begin{tabular}{|c|c|c|}
\hline & $\begin{array}{l}\text { University Hospital } \\
\text { of the Region }\end{array}$ & $\begin{array}{ll}\text { Army hospitals of } \\
\text { Northern Greece }\end{array}$ \\
\hline Characteristics & $\begin{array}{l}\text { Civilian RNs } \\
n=40\end{array}$ & $\begin{array}{l}\text { Army } R N s \\
n=77\end{array}$ \\
\hline Mean age \pm SD (year) & $36,2 \pm 7,5$ & $34,18 \pm 5,95$ \\
\hline Mean duration of nursing \pm SD (year) & $12,16 \pm 8,8$ & $15,07 \pm 6,22$ \\
\hline $\begin{array}{l}\text { Gender } \\
\text { male }\end{array}$ & $5 \%$ & $61 \%$ \\
\hline female & $95 \%$ & $39 \%$ \\
\hline $\begin{array}{l}\text { Age } \\
18-27\end{array}$ & $5 \%$ & $13 \%$ \\
\hline $28-35$ & $30 \%$ & $46,8 \%$ \\
\hline$>36$ & $65 \%$ & $39 \%$ \\
\hline $\begin{array}{l}\text { Additional Education } \\
\text { Nursing specialty }\end{array}$ & $7,5 \%$ & $36,4 \%$ \\
\hline $\mathrm{MSc}$ & - & $2,6 \%$ \\
\hline specialization & $20 \%$ & $7,8 \%$ \\
\hline nothing & $72,5 \%$ & $53,2 \%$ \\
\hline $\begin{array}{l}\text { Marital status: } \\
\text { Married }\end{array}$ & 24 & 55 \\
\hline Single or divorced & 16 & 22 \\
\hline $\begin{array}{l}\text { Kids existence } \\
\text { yes }\end{array}$ & 28 & 49 \\
\hline no & 12 & 28 \\
\hline $\begin{array}{l}\text { Working role } \\
\text { Head nurse }\end{array}$ & $25 \%$ & $13 \%$ \\
\hline Clinical registered nurse & $75 \%$ & $87 \%$ \\
\hline $\begin{array}{l}\text { Working place in hospital } \\
\text { ICU }\end{array}$ & none & $29,9 \%$ \\
\hline operating room & $30 \%$ & $13 \%$ \\
\hline Inpatient services & $32,5 \%$ & $54,5 \%$ \\
\hline Outpatient clinics -ER & $37,5 \%$ & $2,6 \%$ \\
\hline $\begin{array}{l}\text { Working experience } \\
1-5 \text { years }\end{array}$ & $27,5 \%$ & $6,5 \%$ \\
\hline $6-15$ years & $20 \%$ & $45,5 \%$ \\
\hline$>16 y e a r s$ & $52,5 \%$ & $48,1 \%$ \\
\hline $\begin{array}{l}\text { Shifts worked } \\
\text { Morning shift }\end{array}$ & $22,5 \%$ & $55,8 \%$ \\
\hline All shifts & $77,5 \%$ & $44,2 \%$ \\
\hline Mean number of night shifts per person in a month \pm SD & $3,1( \pm 2,668)$ & $2,05( \pm 3,065)$ \\
\hline Mean number of weekend days per month \pm SD & $2,75( \pm 2,227)$ & $2,29( \pm 1,73)$ \\
\hline
\end{tabular}

In table 1 there are all the demographic information of Army RNs and Civilian RNs.

Table 2. Sampling frame

\begin{tabular}{|l|l|}
\hline HOSPITALS & RN (N) \\
\hline ARMY HOSPITAL A IN NORTHERN GREECE & 17 \\
\hline ARMY HOSPITAL B IN NORTHERN GREECE & 18 \\
\hline ARMY HOSPITAL C IN NORTHERN GREECE & 20 \\
\hline ARMY HOSPITAL D IN NORTHERN GREECE & 22 \\
\hline $\begin{array}{l}\text { UNIVERSITY HOSPITAL IN NORTHERN } \\
\text { GREECE }\end{array}$ & 40 \\
\hline
\end{tabular}

In Table 2 there is the sampling frame 
Table 3. Perception of selected job characteristics among Registered Nurses working in Army Hospitals of Northern Greece and Civilian Registered Nurses of a University Hospital of the Region

\begin{tabular}{|c|c|c|}
\hline $\begin{array}{l}\text { Please indicate if you agree or disagree with } \\
\text { the following statements }\end{array}$ & $\begin{array}{l}\text { Civilian RNs } \\
n=40 \\
\text { (percent) }\end{array}$ & $\begin{array}{l}\text { Army } R N s \\
n=77 \\
\text { (percent) }\end{array}$ \\
\hline $\begin{array}{l}\text { Would you like your child to follow a } \\
\text { nursing career? } \\
\text { Yes } \\
\text { no }\end{array}$ & $\begin{array}{l}15 \% \\
85 \%\end{array}$ & $\begin{array}{l}27,3 \% \\
71,4 \%\end{array}$ \\
\hline $\begin{array}{l}\text { Would you choose the nursing profession } \\
\text { again? } \\
\text { Yes } \\
\text { No } \\
\end{array}$ & $\begin{array}{l}37,5 \% \\
62,5 \%\end{array}$ & $\begin{array}{l}46,8 \% \\
53,2 \%\end{array}$ \\
\hline $\begin{array}{l}\text { Do you want to change your everyday duties } \\
\text { in order to feel independent health } \\
\text { professional? } \\
\text { Yes } \\
\text { No } \\
\end{array}$ & $\begin{array}{l}90 \% \\
10 \%\end{array}$ & $\begin{array}{l}83,1 \% \\
16,9 \%\end{array}$ \\
\hline $\begin{array}{l}\text { Do you feel that your opinion counts in the } \\
\text { team with the other health professionals? } \\
\text { Yes } \\
\text { no }\end{array}$ & $\begin{array}{l}32,5 \% \\
67,5 \% \\
\end{array}$ & $\begin{array}{l}42,9 \% \\
57,1 \% \\
\end{array}$ \\
\hline $\begin{array}{l}\text { Do you feel that the doctor-centred model of } \\
\text { Greek Hospitals creates difficulties in the } \\
\text { team work? } \\
\text { Yes } \\
\text { No }\end{array}$ & $\begin{array}{l}87,5 \% \\
12,5 \%\end{array}$ & $\begin{array}{l}77,9 \% \\
22,1 \%\end{array}$ \\
\hline $\begin{array}{l}\text { Do you believe that the nursing profession is } \\
\text { socially awarded? } \\
\text { Yes } \\
\text { no }\end{array}$ & $\begin{array}{l}15 \% \\
85 \%\end{array}$ & $\begin{array}{l}36,4 \% \\
63,6 \%\end{array}$ \\
\hline $\begin{array}{l}\text { Do you believe that there is huge dimension } \\
\text { between your professional expectations and } \\
\text { the reality you live in? } \\
\text { Yes } \\
\text { no }\end{array}$ & $\begin{array}{l}97,5 \% \\
2,5 \%\end{array}$ & $\begin{array}{l}90,9 \\
9,1\end{array}$ \\
\hline $\begin{array}{l}\text { Willingness to quit } \\
\text { Yes } \\
\text { No }\end{array}$ & $\begin{array}{l}25 \% \\
75 \%\end{array}$ & $\begin{array}{l}33,8 \% \\
66,2 \%\end{array}$ \\
\hline
\end{tabular}

In table 3 there are the respondents' perception of selected job characteristics among Registered Nurses working in Army Hospitals of Northern Greece and Civilian Registered Nurses of a University Hospital of the Region 
Table 4. Job related tension index

\begin{tabular}{|c|c|c|c|c|c|c|c|c|}
\hline \multirow[t]{2}{*}{ Items } & \multicolumn{4}{|c|}{ Army RN } & \multicolumn{4}{|c|}{ Civilian $R N$} \\
\hline & Mean & - median & $\min -\max$ & SD & Mean & - median & $\min -\max$ & $S D$ \\
\hline $\begin{array}{l}\text { 1. feeling that you have too } \\
\text { heavy a workload one that } \\
\text { you cant possibly finish } \\
\text { during an ordinary } \\
\text { workday }\end{array}$ & 3,04 & -3 & $1-5$ & ,952 & 3,65 & 4 & $1-5$ & 1,027 \\
\hline $\begin{array}{l}\text { 2. feeling that you are not } \\
\text { fully qualified to handle } \\
\text { your job }\end{array}$ & 2,16 & $-\quad 2$ & $1-4$ & ,779 & 2,25 & -2 & $1-5$ & ,899 \\
\hline $\begin{array}{l}\text { 3.thinking that you will not } \\
\text { be able to satisfy the } \\
\text { conflicting demands of } \\
\text { various people over you }\end{array}$ & 2,95 & -3 & $1-5$ & 1,025 & 2,73 & & $1-5$ & ,905 \\
\hline $\begin{array}{l}\text { 4. not knowing that your } \\
\text { supervisor thinks of you, } \\
\text { how he (she) evaluates } \\
\text { your performance }\end{array}$ & 2,31 & -2 & $1-5$ & 1,115 & 2,35 & -2 & $1-4$ & ,949 \\
\hline $\begin{array}{l}\text { 5. having to decide things } \\
\text { that affect the lives of } \\
\text { individuals, people that } \\
\text { you know }\end{array}$ & 3,05 & -3 & $1-5$ & 1,075 & 3,25 & -3 & $1-5$ & 1,149 \\
\hline $\begin{array}{l}\text { 6. feeling that you may not } \\
\text { be liked and accepted by } \\
\text { the people you work with }\end{array}$ & 2,45 & -2 & $1-5$ & ,940 & 2,58 & $-\quad 2,50$ & $1-5$ & 1,083 \\
\hline $\begin{array}{l}\text { 7. feeling unable to } \\
\text { influence your immediate } \\
\text { supervisor's decisions and } \\
\text { actions that affect you }\end{array}$ & 3,05 & -3 & $1-5$ & 1,012 & 2,80 & -3 & $1-5$ & 1,043 \\
\hline $\begin{array}{l}\text { 8. Not knowing just what } \\
\text { the people you work with } \\
\text { expect of you. }\end{array}$ & 2,36 & -2 & $1-4$ & ,776 & 2,48 & 2 & $1-5$ & 1,037 \\
\hline $\begin{array}{l}\text { 9. thinking that the amount } \\
\text { of work you have to may } \\
\text { interfere with how well it } \\
\text { gets done }\end{array}$ & 3,06 & -3 & $1-5$ & ,964 & 3,28 & -3 & $1-5$ & 1,037 \\
\hline $\begin{array}{l}\text { 10. feeling that you have to } \\
\text { do things on the job that } \\
\text { are against your better } \\
\text { judgment }\end{array}$ & 2,64 & -2 & $1-5$ & 1,050 & 2,78 & -3 & $1-5$ & 1,000 \\
\hline $\begin{array}{l}\text { 11. feeling that your job } \\
\text { tends to interfere with your } \\
\text { family life }\end{array}$ & 3,65 & -4 & $1-5$ & 1,061 & 3,55 & -4 & $1-5$ & 1,197 \\
\hline sum & & 29 & $11-53$ & & & 31,50 & $11-54$ & \\
\hline
\end{tabular}

Table 4 describe mean, medians, min and max and standard deviations in job related tension index items of Army RNs and civilian RNs 
Table 5. Different items of job satisfaction from Warr- Cook Wall scale

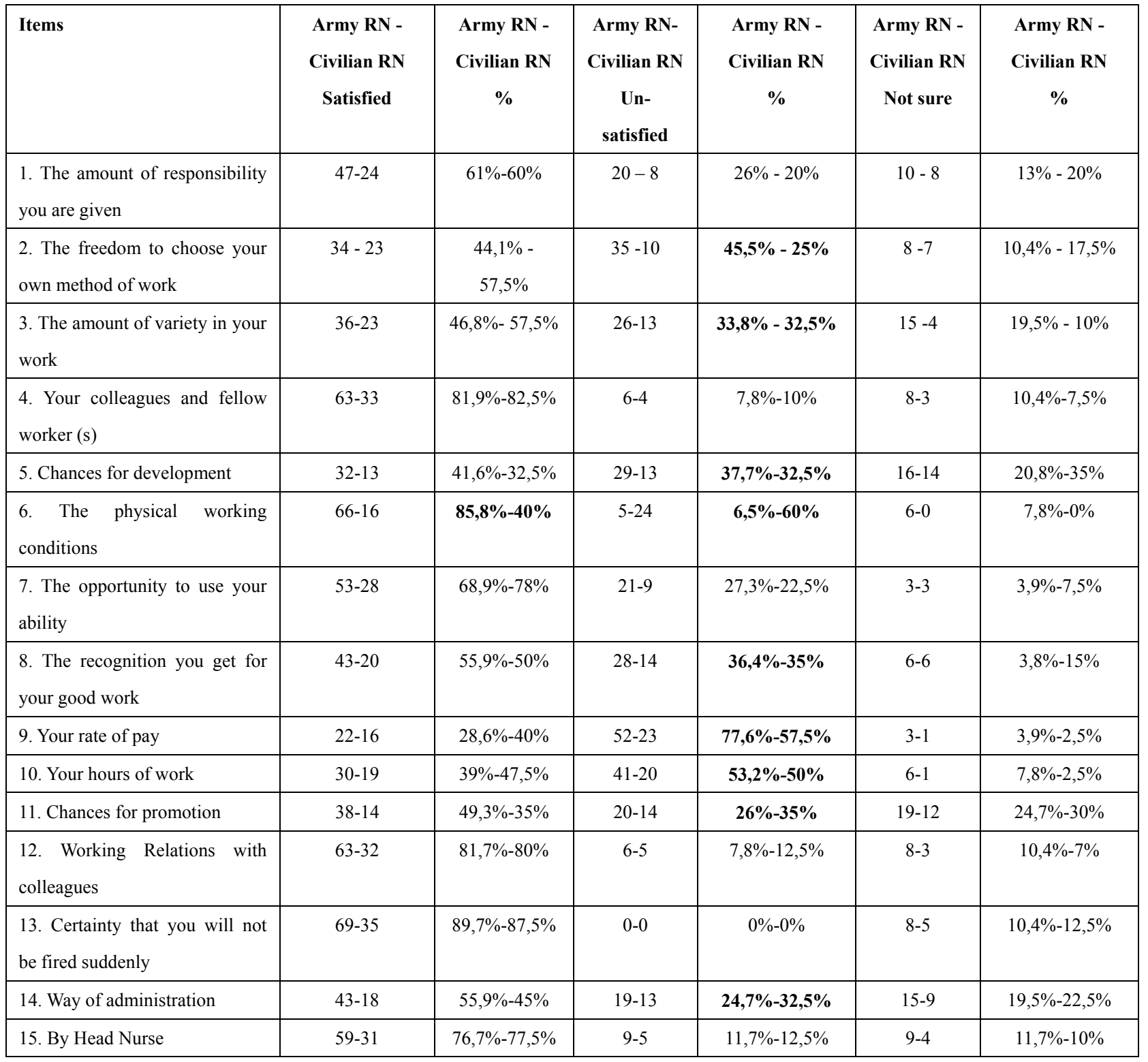

Table 5 describes the satisfaction with different items of job satisfaction from Warr- Cook Wall scale of Army RNs and civilian RNs 
Table 6. Average job satisfaction among Army registered and civilian RNs

\begin{tabular}{|c|c|c|c|c|c|c|}
\hline & \multicolumn{3}{|c|}{ military registered nurses $\quad \mathrm{n}=77$} & \multicolumn{3}{|c|}{ Civilian registered Nurse $n=40$} \\
\hline & \multicolumn{3}{|c|}{ Items of job satisfaction } & \multicolumn{3}{|c|}{ Items of job satisfaction } \\
\hline & Mean & SD & p-value & Mean & SD & p-value \\
\hline $\begin{array}{l}\text { marital status } \\
\text { Married } \\
\text { Single-divorced } \\
\end{array}$ & $\begin{array}{l}\text { Freedc } \\
\mathbf{4 , 0 7} \\
\mathbf{3 , 3 3} \\
\end{array}$ & $\begin{array}{r}\text { method } \\
\mathbf{1 , 6 4 3} \\
\mathbf{1 , 2 3 8} \\
\end{array}$ & $p=0,049$ & $\begin{array}{l}\text { Workir } \\
\mathbf{5 , 1 7} \\
\mathbf{5 , 0 7} \\
\end{array}$ & $\begin{array}{r}\text { with coll } \\
\mathbf{0 , 9 6 3} \\
\mathbf{1 , 5 8 0} \\
\end{array}$ & $\mathbf{p}=\mathbf{0 , 0 1 9}$ \\
\hline $\begin{array}{l}\text { Children } \\
\text { Yes } \\
\text { No }\end{array}$ & $\begin{array}{l}\text { Hours } \\
\mathbf{3 , 8 8} \\
\mathbf{3 , 0 8} \\
\text { Collea } \\
\mathbf{5 , 3 3} \\
\mathbf{5 , 2 8}\end{array}$ & $\begin{array}{r}1,763 \\
1,441 \\
\text { low work } \\
1,313 \\
\mathbf{0 , 6 1 4}\end{array}$ & $\begin{array}{l}\mathbf{p}=\mathbf{0 , 0 3 9} \\
\mathbf{p}=\mathbf{0 , 0 0 7}\end{array}$ & $\begin{array}{l}\text { Amoun } \\
\mathbf{4 , 4 6} \\
\mathbf{5 , 5 0}\end{array}$ & $\begin{array}{l}\text { job } \\
\mathbf{1 , 2 3 2} \\
\mathbf{0 , 0 0 0}\end{array}$ & $p=0,049$ \\
\hline $\begin{array}{l}\text { additional education } \\
\text { yes } \\
\text { no }\end{array}$ & & & & $\begin{array}{l}\text { Freedo } \\
\mathbf{4 , 8 2} \\
\mathbf{4 , 1 0} \\
\text { Opport } \\
\mathbf{5 , 2 7} \\
\mathbf{4 , 5 2} \\
\text { Amoun } \\
\mathbf{4 , 9 1} \\
\mathbf{4 , 0 0}\end{array}$ & $\begin{array}{c}\text { method } \\
\mathbf{0 , 8 7 4} \\
\mathbf{1 , 4 7 2} \\
\text { abilities } \\
\mathbf{0 , 9 0 5} \\
\mathbf{1 , 4 5 5} \\
\text { n job } \\
\mathbf{0 , 9 4 4} \\
\mathbf{1 , 5 3 5}\end{array}$ & $\begin{array}{l} \\
p=0,039 \\
p=0,034 \\
p=0,019\end{array}$ \\
\hline $\begin{array}{l}\text { choose again the same } \\
\text { profession } \\
\text { yes } \\
\text { no }\end{array}$ & $\begin{array}{l}\text { Oppor } \\
\mathbf{5 , 0 6} \\
\mathbf{3 , 9 8}\end{array}$ & $\begin{array}{c}\text { abilities } \\
1,308 \\
1,508\end{array}$ & $p=0,024$ & $\begin{array}{l}\text { Head N } \\
\mathbf{4 , 8 0} \\
\mathbf{5 , 0 4}\end{array}$ & $\begin{array}{l}1,935 \\
0,978\end{array}$ & $\mathrm{p}=\mathbf{0 , 0 3 2}$ \\
\hline $\begin{array}{l}\text { willingness to resign and quit } \\
\text { profession } \\
\text { yes } \\
\text { no }\end{array}$ & & & & $\begin{array}{l}\text { Freedo } \\
\mathbf{4 , 9 0} \\
\mathbf{4 , 1 0} \\
\text { Opport } \\
\mathbf{5 , 1 0} \\
\mathbf{4 , 6 0} \\
\end{array}$ & $\begin{array}{c}\text { method } \\
\mathbf{0 , 8 7 6} \\
\mathbf{1 , 4 4 7} \\
\text { abilities } \\
\mathbf{0 , 8 7 6} \\
\mathbf{1 , 4 7 6} \\
\end{array}$ & $\begin{array}{l}g \\
p=0,042 \\
p=0,014\end{array}$ \\
\hline $\begin{array}{l}\text { Willingness the child to } \\
\text { follow nursing profession } \\
\text { Yes } \\
\text { no }\end{array}$ & $\begin{array}{l}\text { Chanc } \\
\mathbf{4 , 7 1} \\
\mathbf{3 , 6 4} \\
\text { Freedc } \\
\mathbf{4 , 8 6} \\
\mathbf{3 , 5 1} \\
\text { job r } \\
\mathbf{5 , 3 8} \\
\mathbf{3 , 8 9}\end{array}$ & $\begin{array}{l}\text { tion } \\
1,146 \\
1,532 \\
\text { method } \\
0,964 \\
1,585 \\
\text { or good w } \\
0,973 \\
1,583\end{array}$ & $\begin{array}{r}\mathbf{p}=\mathbf{0 , 0 3 4} \\
\mathbf{p}=\mathbf{0 , 0 0 1} \\
\mathbf{p}=\mathbf{0 , 0 0 1}\end{array}$ & & & \\
\hline $\begin{array}{l}\text { Willingness to modify job } \\
\text { description } \\
\text { Yes } \\
\text { no }\end{array}$ & $\begin{array}{l}\text { Oppor } \\
\mathbf{4 , 5 5} \\
\mathbf{4 , 1 5} \\
\text { Amou } \\
\mathbf{4 , 1 3} \\
\mathbf{3 , 8 5}\end{array}$ & $\begin{array}{l}\text { abilities } \\
\mathbf{1 , 3 3 2} \\
\mathbf{2 , 2 3 0} \\
\text { in job } \\
\mathbf{1 , 2 7 9} \\
\mathbf{1 , 9 0 8}\end{array}$ & $\begin{array}{l}p=0,001 \\
p=0,028\end{array}$ & $\begin{array}{l}\text { Amoun } \\
\mathbf{4 , 1 9} \\
\mathbf{4 , 7 5} \\
\text { job rec } \\
\mathbf{4 , 5 8} \\
\mathbf{3 , 7 5} \\
\text { Certain } \\
\mathbf{5 , 9 7} \\
\mathbf{5 , 5 0} \\
\end{array}$ & $\begin{array}{l}\text { n job } \\
\mathbf{1 , 5 0 8} \\
\mathbf{0 , 5 0 0} \\
\text { good wo } \\
\mathbf{1 , 0 7 9} \\
\mathbf{2 , 2 1 7} \\
\text { fill not b } \\
\mathbf{0 , 9 7 1} \\
\mathbf{1 , 7 3 2} \\
\end{array}$ & $\begin{array}{c}\mathbf{p}=\mathbf{0 , 0 2 4} \\
\mathbf{p}=\mathbf{0 , 0 1 6} \\
\text { ddenly } \\
\mathbf{p}=\mathbf{0 , 0 1 8}\end{array}$ \\
\hline
\end{tabular}

Table 6 describes average job satisfaction among Army registered and civilian RNs 
Table 7. Median job satisfaction scores among army registered nurses and Civilian registered Nurses

\begin{tabular}{|c|c|c|}
\hline Items of job satisfaction & $\begin{array}{l}\text { army registered nurses } \\
\mathbf{n}=77 \\
\text { median (min-max) }\end{array}$ & $\begin{array}{l}\text { Civilian registered Nurses } \\
\mathbf{n}=\mathbf{4 0} \\
\text { median (min-max) }\end{array}$ \\
\hline 1. Colleagues and fellow workers & $5(1-7)$ & $5(2-7)$ \\
\hline 2. Physical working conditions & $3(1-7)$ & $5(1-7)$ \\
\hline 3. Amount of variety in job & $4(1-7)$ & $5(1-7)$ \\
\hline 4. Amount of responsibility & $5(1-7)$ & $5(1-7)$ \\
\hline $\begin{array}{l}\text { 5. Freedom to choose method of } \\
\text { working }\end{array}$ & $4(1-7)$ & $5(1-6)$ \\
\hline 6. Opportunity to use abilities & $5(1-7)$ & $5(2-7)$ \\
\hline 7. Satisfaction with job recognition for good work & $5(1-7)$ & $4,5(1-6)$ \\
\hline 8. Remuneration & $3(1-7)$ & $3(1-6)$ \\
\hline 9. Hours of work & $3(1-7)$ & $3,5(1-7)$ \\
\hline 10. Chances for promotion & $4(1-7)$ & $4(1-7)$ \\
\hline 11. Working Relations with colleagues & $5(2-7)$ & $5(2-7)$ \\
\hline 12. Certainty that you will not be fired suddenly & $6(4-7)$ & $6(4-7)$ \\
\hline 13. administration & $5(1-7)$ & $4(1-7)$ \\
\hline 14. Head Nurse & $6(1-7)$ & $5(1-7)$ \\
\hline 15. Chances for development & $4(1-7)$ & $4(1-7)$ \\
\hline total & $67(19-105)$ & $69(21-102)$ \\
\hline
\end{tabular}

Table 7 describes Median job satisfaction scores among army registered nurses and Civilian registered Nurses 
Table 8. Pearson correlation results of items of job satisfaction scale and certain personal and professional characteristics (ARMY RNs)

\begin{tabular}{|c|c|c|c|c|c|c|c|c|c|c|c|c|c|c|c|c|}
\hline & ${ }^{1} \mathrm{a}$ & $b^{2}$ & $c^{3}$ & $d^{4}$ & $e^{5}$ & $f^{6}$ & $\mathrm{~g}^{7}$ & $h^{8}$ & $i^{9}$ & $\mathrm{j}^{10}$ & $\mathrm{k}^{11}$ & $1^{12}$ & $\mathrm{~m}^{13}$ & $\mathrm{n}^{14}$ & $\mathrm{o}^{15}$ & $p^{16}$ \\
\hline \multirow[t]{2}{*}{ age } & $\begin{array}{c}, 325^{*} \\
*\end{array}$ &, $294 * *$ &, $345^{* *}$ & ,154 & ,279* & ,282* & ,151 & ,159 & ,042 & ,057 & ,043 & , 180 &, $363 * *$ &, $395 * *$ &, 117 & $\begin{array}{c}, 363 \\
* *\end{array}$ \\
\hline &, 004 & ,009 & ,002 & ,181 &, 014 & ,013 & 191 & ,169 & ,720 & ,622 & ,710 & ,118 & ,001 &, 000 & ,313 & ,001 \\
\hline \multirow[t]{2}{*}{$\begin{array}{c}\text { Years of } \\
\text { service }\end{array}$} & ,256* &, $254^{*}$ &, $300 * *$ & ,151 & ,235* & ,231* & ,094 & ,124 & ,060 & ,021 & ,073 & ,156 &, $319 * *$ &, $401 * *$ & ,207 & $\begin{array}{c}, 326 \\
* *\end{array}$ \\
\hline &, 024 & ,026 & ,008 & , 190 &, 040 & ,043 & ,415 & ,283 & 601 & 859 &, 530 & ,177 & ,005 & ,000 &, 071 & ,004 \\
\hline \multirow[t]{2}{*}{$\begin{array}{c}\text { Mean } \\
\text { days } \\
\text { weekend } \\
\text { work per } \\
\text { month }\end{array}$} &,- 024 &,- 038 &,- 127 & $\begin{array}{c}-, 02 \\
8\end{array}$ &,- 107 &,- 140 & $\begin{array}{c}-, 04 \\
8\end{array}$ &,- 101 & ,043 &,- 199 & $\begin{array}{c}-, 02 \\
0\end{array}$ &,- 102 &,$- 241 *$ &,- 183 &,- 181 &,- 163 \\
\hline & ,838 & ,743 & ,272 & ,809 &, 354 & ,225 & 681 &, 380 & ,713 & ,083 & ,860 & ,379 & ,034 & ,112 & ,115 & ,155 \\
\hline \multirow[t]{2}{*}{$\begin{array}{c}\text { Mean } \\
\text { days night } \\
\text { shift per } \\
\text { month }\end{array}$} &,- 001 &,- 142 &,- 166 & $\begin{array}{c}-, 11 \\
6\end{array}$ &,- 105 &,- 137 & $\begin{array}{c}-, 06 \\
9\end{array}$ &,- 104 & ,071 &,- 177 & ,124 &,- 111 & $\begin{array}{c}-, 332 * \\
*\end{array}$ &,$- 277^{*}$ &,- 103 & $\begin{array}{c}-, 233 \\
*\end{array}$ \\
\hline & ,992 & ,217 & ,149 & ,313 &, 365 & ,236 & ,552 &, 367 & ,538 & ,123 & ,281 & ,336 & ,003 & ,015 & ,375 &, 041 \\
\hline \multirow{2}{*}{$\begin{array}{c}\text { JDS } \\
\text { TENSIO } \\
\mathrm{N} \\
\end{array}$} &,- 059 &,- 179 &,- 080 & $\begin{array}{c}-, 17 \\
9\end{array}$ &,- 120 &,- 086 & $\begin{array}{c}-, 08 \\
3\end{array}$ & $\begin{array}{c}-, 241 \\
*\end{array}$ & $\begin{array}{c}-, 17 \\
1\end{array}$ & $\begin{array}{c}-, 257 \\
*\end{array}$ & ,059 & $\begin{array}{c}-, 333 * \\
*\end{array}$ & $\begin{array}{c}-, 402 * \\
*\end{array}$ & $\begin{array}{c}-, 325^{*} \\
*\end{array}$ & ,023 & $\begin{array}{c}-, 232 \\
*\end{array}$ \\
\hline & ,610 & 119 & ,487 & , 120 &, 300 & ,455 & ,472 &, 035 & ,138 & ,024 & 610 & ,003 & ,000 & ,004 & 841 & ,042 \\
\hline
\end{tabular}

** Correlation is significant at the 0.01 level (2-tailed).

* Correlation is significant at the 0.05 level (2-tailed).

Table 8 describes Pearson correlation results of items of job satisfaction scale and certain personal and professional characteristics (ARMY RNs)

Notes:

1 Freedom to choose method of working

2 job recognition for good work

${ }^{3}$ Amount of responsibility

${ }^{4}$ Opportunity to use abilities

${ }^{5}$ Chances for promotion

${ }^{6}$ Chances for development

${ }^{7}$ Amount of variety in job

${ }^{8}$ Physical working conditions

${ }^{9}$ Colleagues and fellow workers

${ }^{10}$ Head Nurse

11 Remuneration

12 Working Relations with colleagues

${ }^{13}$ Working Relations with colleagues

${ }^{14}$ Hours of work

${ }^{15}$ Certainty that you will not be fired suddenly

${ }^{16}$ satisfaction 
Table 9. Pearson correlation results of items of job satisfaction scale and certain personal and professional characteristics (CIVILIAN RNs)

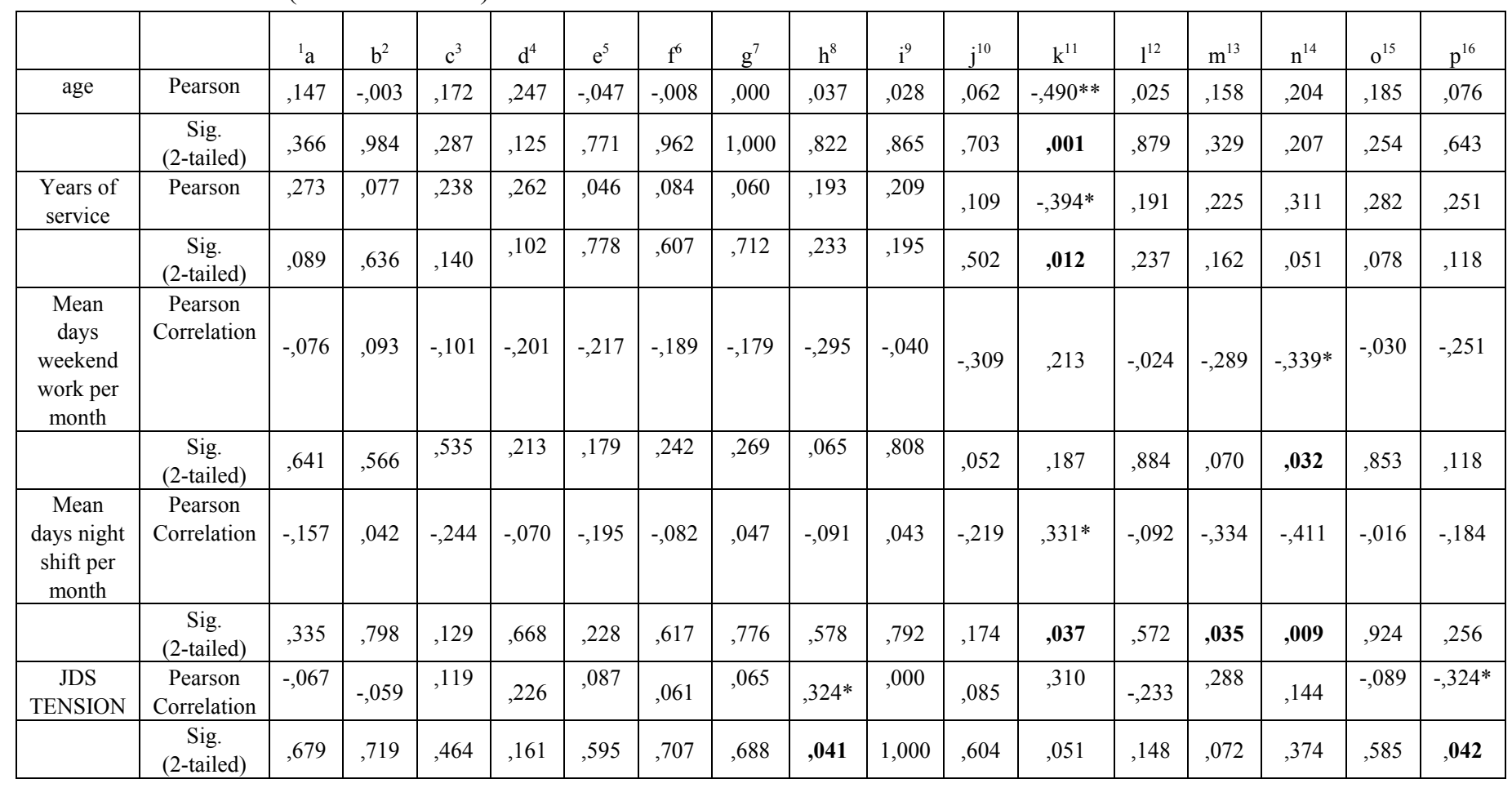

** Correlation is significant at the 0.01 level (2-tailed).

* Correlation is significant at the 0.05 level (2-tailed).

Table 9 describes Pearson correlation results of items of job satisfaction scale and certain personal and professional characteristics (CIVILIAN RNs)

Notes:

1 Freedom to choose method of working

2 job recognition for good work

3 Amount of responsibility

${ }^{4}$ Opportunity to use abilities

5 Chances for promotion

${ }^{6}$ Chances for development

7 Amount of variety in job

8 Physical working conditions

${ }^{9}$ Colleagues and fellow workers

${ }^{10}$ Head Nurse

11 Remuneration

12 Working Relations with colleagues

13 Working Relations with colleagues

${ }^{14}$ Hours of work

15 Certainty that you will not be fired suddenly

16 satisfaction 